\title{
Fosterdiagnostikk med blodprøver
}

\author{
Fosterdiagnostikk med cellefritt føtalt DNA i mors blod er verken en vidunderlig ny verden eller dens \\ undergang. I debatten må ikke frykten for misbruk få overskygge fordelene ved dagens foreslåtte bruk.
}

Da skotske forskere klonet sauen Dolly i 1996 (1), mente noen at en vidunderlig ny verden var her - andre at verdens undergang var nær. Men 17 år senere har ingen hittil klonet et menneske. Hysteriet rundt kloning av sau ble en moderne versjon av eventyret om gjetergutten som ropte om ulven - som ikke kom.

I dag er det fosterdiagnostikk med blodprøver som skaper skrekk og begeistring. Cellefritt føtalt DNA i gravide kvinners blod kan påvise egenskaper ved fosteret allerede i første trimester. Noen frykter at gravide vil ta blodprøver og sortere fostre ut fra kjønn eller andre egenskaper før grensen for selvbestemt abort. Debatten pågår også i Tidsskriftets spalter $(2,3)$. Problemet er at det fokuseres på etiske problemstillinger og mulig misbruk av metoden, mens gevinster ved dagens foreslåtte bruk ikke når frem.

\section{En metode, ikke en spesifikk test} Analyse av cellefritt føtalt DNA er en metode som kan brukes til å undersøke ulike tilstander i fosterlivet. Metoden er foreløpig ikke tilgjengelig for klinisk bruk i Norge, men det er to bruksområder som er aktuelle. Metoden kan bestemme fosterets rhesusblodgruppe når mor er rhesusnegativ, og man kan teste om fosteret har en arvelig lidelse eller en kromosomfeil. Analyse av cellefritt føtalt DNA som test for rhesusblodgruppe er sannsynligvis ukontroversielt i Norge, men som test for Downs syndrom skaper metoden debatt.

\section{Kan forhindre rhesusimmunisering}

Ca. $15 \%$ av norske kvinner er rhesusnegative og må ta blodprøver i svangerskapet og av det nyfødte barnet. Ca. $60 \%$ av barna er rhesuspositive (4). Da får mor en sprøyte med antistoffer (anti-D) kort tid etter fødsel for å forhindre at hun selv danner antistoffer som kan gi problemer i et eventuelt senere svangerskap. I Norge får gravide som er rhesusnegative også anti-D ved fostervannsprøve, vendingsforsøk av seteleie og ved store blødninger i svangerskapet. Noen land (f.eks. England) gir rutinemessig anti-D i tredje trimester til alle gravide som er rhesusnegative. Dette reduserer risikoen for immunisering fra $1,5 \%$ til $0,5 \%$ (5). Det blir ikke gjort i Norge, fordi $40 \%$ av alle gravide som er rhesusnegative vil ha et foster som er rhesuskompatibelt.

Rutinemessig anti-D i tredje trimester uten å vite fosterets blodgruppe betyr overbehandling av en stor gruppe kvinner. Ved å bruke cellefritt føtalt DNA kan man der- imot påvise hvilke fostre som er rhesuspositive med tilnærmet $100 \%$ treffsikkerhet (6) og gi anti-D til disse kvinnene både i tredje trimester og etter fødsel (4). Det er bred internasjonal enighet om at dette er et fremskritt som kan redde liv ved å gi færre immuniseringer. Danmark og Nederland har allerede innført analyse av cellefritt føtalt DNA i oppfølging av gravide som er rhesusnegative. Sverige og Norge venter på en økonomisk analyse fra et prosjekt i Stockholm i 2009-11 (4). Innføring av et slikt program vil være ukontroversielt i Norge dersom det viser seg samfunnsøkonomisk nyttig.

\section{Tryggere testing av kromosomfeil}

I Norge tilbys kvinner over 38 år kombinert ultralyd og blodprøve (KUB). Hensikten er å påvise kromosomfeil. Det gjøres ca. 3500 KUB-tester hvert år i Norge, og 10-15\% av kvinnene tar invasive prøver (fostervannsprøver og morkakeprøver) (3). Det betyr at det gjøres 350-500 invasive prøver etter kombinert ultralyd og blodprøve. Invasive prøver har en abortrisiko på ca. $1 \%$, dvs. at det aborteres 3-5 friske fostre pga. prøvetaking hvert år i Norge. Ved bruk av cellefritt føtalt DNA som annenlinjetest etter kombinert ultralyd og blodprøve vil antallet invasive prøver reduseres (7), og antallet utilsiktede aborter kan reduseres fra 3-5 til 0-1 per år i Norge. Det er lett å argumentere med at metoden gir tryggere testing av kromosomfeil når det blir færre invasive prøver og utilsiktede aborter.

\section{Kan spare penger}

Analysekostnadene ved cellefritt føtalt DNA er høye (500-1 500 dollar per prøve) (8), men allerede i dag er kostnadene tilsvarende som for invasive prøver, og de vil reduseres ytterligere. Enkle beregninger viser at man kan spare penger ved å innføre metoden. Ved Skånes Universitetssjukhus tilbys alle kvinner over 33 år kombinert ultralyd og blodprøve, og det gjøres ca. 2000 av disse testene og 150 invasive prover hvert år (administrative data). Invasiv prøvetaking og analyse koster sykehuset 6700 svenske kroner per prøve og ca. én million kroner per år. Sykehuset vil innføre analyse av cellefritt føtalt DNA som annenlinjetest og har satt kostnaden til ca. 5000 svenske kroner per prøve (Maria Soller, personlig meddelelse). Antallet invasive prøver vil kunne reduseres fra 150 til ca. $7-10$ per år (7). En enkel beregning viser at analysekostnadene reduseres med ca.
200000 kroner årlig. Analyse av cellefritt føtalt DNA som annenlinjetest etter kombinert ultralyd og blodprøve vil dermed gi skånske kvinner et bedre tilbud for lavere kostnad.

\section{Kan ikke erstatte ultralyd}

Det diskuteres om analyse av cellefritt føtalt DNA helt eller delvis kan erstatte KUB-test, og om metoden kan brukes som førstelinjetest $i$ et screeningprogram for kromosomfeil (7-9). I dag kan ikke analyse av cellefritt føtalt DNA som test for trisomi gjøres uten ultralydundersøkelse. Man må vite om fosteret lever og om det er flerlinger. I tillegg er ultralyd den beste metoden til å bestemme svangerskapslengde og til å oppdage alvorlige strukturelle utviklingsavvik som analyse av cellefritt føtalt DNA ikke vil avsløre (8). Ultralyd før analyse av cellefritt føtalt DNA bør gjøres av lege/ jordmor som er utdannet og har godkjenning, slik vi krever av helsepersonell som utfører kombinert ultralyd og blodprøve. Å la ultralydundersøkelsen gjøres av helsepersonell uten utdanning og uten kvalitetssikring vil være et vesentlig dårligere tilbud til gravide. Derfor vil analyse av cellefritt føtalt DNA som førstelinjetest uten kvalitetssikret ultralyd være et dårlig tilbud selv i en høyrisikopopulasjon (kvinner over 38 år). I Skåne og i Danmark diskuteres for tiden innføring av analyse av cellefritt føtalt DNA som annenlinjetest etter kombinert ultralyd og blodprøve. Ingen land har, etter det jeg kjenner til, innført metoden som førstelinjetest for kromosomfeil.

\section{Hva med fremtiden?}

I fremtiden vil man trolig kunne gjøre helgenomsekvensering av cellefritt føtalt DNA og bestemme genetiske egenskaper tidlig i svangerskapet (2). Men spørsmålet om hvordan vi skal håndtere informasjon fra helgenomsekvensering gjelder ikke bare i fosterlivet, men også for barn og voksne $i$ alle aldre. Debatt er viktig, men dagens foreslåtte bruk av cellefritt føtalt DNA er for rhesusblodgruppe og som annenlinjetest etter kombinert ultralyd og blodprøve. Dette bør være ukontroversielt - også i Norge.

\section{Kjell Åsmund Salvesen}

pepe.salvesen@ntnu.no 
Kjell Åsmund Salvesen (f. 1958) er spesialist i fødselshjelp og kvinnesykdommer, med spesialkompetanse i ultralyd og fostermedisin. Han er overlege og professor ved Skånes Universitetssjukhus og Lunds Universitet og i bistilling ved St. Olavs hospital og Norges teknisk-naturvitenskapelige universitet. Han er medlem av Helsedirektoratets rådgivende bioreferansegruppe for perioden 2013-16, som flere ganger har behandlet spørsmålet om bruk av fosterdiagnostikk med analyse av cellefritt føtalt DNA.

Forfatter har fylt ut ICMJE-skjemaet og oppgir ingen interessekonflikter.

\section{Litteratur}

1. Campbell KHS, McWhir J, Ritchie WA et al. Sheep cloned by nuclear transfer from a cultured cell line. Nature 1996; 380: 64-6.

2. Hofmann B. Forbedret fosterdiagnostikk? Tidsskr Nor Legeforen 2013; 133: 2336.

3. Hov GG, Åsberg A, Thorstensen K. Kommenta til leder. http://tidsskriftet.no/article/3103954/

4. Tiblad E, Taune Wikman A, Ajne G et al. Targeted routine antenatal anti-D prophylaxis in the prevention of RhD immunisation-outcome of a new antenatal screening and prevention program. PLoS ONE 2013; 8: e70984.

5. Jones ML, Wray J, Wight J et al. A review of the clinical effectiveness of routine antenatal anti-D prophylaxis for rhesus-negative women who are pregnant. BJOG 2004; 111: 892-902.

6. Wikman AT, Tiblad E, Karlsson A et al. Noninvasive single-exon fetal RHD determination in a routine screening program in early pregnancy. Obstet Gynecol 2012; 120: 227-34

7. Nicolaides KH, Wright D, Poon LC et al. First-trimester contingent screening for trisomy 21 by biomarkers and maternal blood cell-free DNA testing. Ultrasound Obstet Gynecol 2013; 42: 41-50.

8. Benn P, Cuckle H, Pergament E. Non-invasive prenatal testing for aneuploidy: current status and future prospects. Ultrasound Obstet Gynecol 2013. 42: 15-33.

9. Gil MM, Quezada MS, Bregant B et al. Implementation of maternal blood cell-free DNA testing in early screening for aneuploidies. Ultrasound Obstet Gynecol 2013; 42: 34-40.

Mottatt 15.12. 2013, første revisjon innsendt 10.1. 2014, godkjent 22.1. 2014. Redaktør: Matilde Risopatron Berg.

Publisert først på nett 